\title{
Miranda
}

Revue pluridisciplinaire du monde anglophone /

Multidisciplinary peer-reviewed journal on the English-

speaking world

$6 \mid 2012$

Marking the Land in North America

\section{Michael Bracewell and Nicholas Cullinan, Alessandro Raho}

\section{Muriel Adrien}

\section{OpenEdition}

\section{Journals}

Electronic version

URL: http://journals.openedition.org/miranda/3127

DOI: $10.4000 /$ miranda.3127

ISSN: 2108-6559

Publisher

Université Toulouse - Jean Jaurès

\section{Electronic reference}

Muriel Adrien, "Michael Bracewell and Nicholas Cullinan, Alessandro Raho", Miranda [Online], 6 | 2012,

Online since 28 June 2012, connection on 16 February 2021. URL: http://journals.openedition.org/ miranda/3127; DOI: https://doi.org/10.4000/miranda.3127

This text was automatically generated on 16 February 2021.

\section{c) (i) (9)}

Miranda is licensed under a Creative Commons Attribution-NonCommercial-NoDerivatives 4.0 International License. 


\title{
Michael Bracewell and Nicholas Cullinan, Alessandro Raho
}

\author{
Muriel Adrien
}

\section{REFERENCES}

Michael Bracewell and Nicholas Cullinan, Alessandro Raho (Farnham: Lund Humphries, 2011), 142 p, ISBN 978-I-84822-093-5

1 This book is the first monograph of Alessandro Raho (born in 1971), a well-known figure in contemporary figurative painting, whose work is of a sober and restrained classicism as opposed to his fellow YBA. The very publication of this monograph acknowledges and celebrates Raho's talent, enhancing his status as a key figure of the contemporary art world. The first author, Michael Bracewell, has also written on other contemporary artists-such as Anish Kapoor, Sam Taylor-Wood, Bridget Riley and Gilbert \& George-, and the second author, Nicholas Cullinan, is curator of International Modern Art at Tate Modern.

2 The order of the essays is consistent and logical. After a short sketchy biography of the artist in an introduction by Thomas Williams, the first essay is rather descriptive, zooming in on some works of Raho, evoking at times earlier artists (photographers as well as painters) from which he drew his inspiration. The second essay is more analytical and a little more comprehensive when it tries to connect Raho's work with earlier works from the art historical canon, although both essays are quite complementary in that respect. A short addendum by Catherine Wood (an essay reprinted from a 2008 exhibition catalogue) is provided at the end, as well as a curriculum vitae of Raho, and a list of illustrations.

3 The introduction by Thomas Williams gives some biographical elements, such as Raho's first years in the Bahamas with his English and Austro-Hungarian mother and Italian father before they separated, his childhood in South London, his time in Goldsmith College and the fact he was the youngest to exhibit in the groundbreaking exhibition 
Brilliant! New Art from London (1997). His then hard-edged portraits evolved into more sophisticated work with a greater sense of modeling and texture. Williams spots various influences, such as the photographers Thomas Struth or Richard Avedon, but more relevantly it seems, Thomas Ruff-whose unsmiling and deliberately expressionless frontal portraits against a white backdrop are obvious references. Williams presents the mingling of subject matter such as landscape and portraiture as original when it is hardly unique in art history: Gainsborough is a case in point.

Bracewell carries on giving factual descriptions of some of his paintings, which is one effective way of making readers concentrate on them without flipping the pages too quickly, although the paintings are usually on different pages, which does not make for very smooth reading. Bracewell ventures on the risky terrain of psychological interpretations of the characters, which seem at times a little hazardous, although his repeating that the sitters are both acquiescent and guarded, neither anticipating nor relaxing, is very convincing throughout. When he insists upon "the subsonic quality of empathetic recognition" (26), it seems more wishful thinking than anything else.

5 He notes that the outfits, clothing and the backdrop are very consciously chosen, although he says there is no sartorial affectation per se, the intention being solely aesthetic, and fabric acting more so as "signage". Floral patterns recall late nineteenthcentury vibrant arts and craft wallpaper, and Cullinan, in the second essay, does not elude the metapictorial nature of the fabric. Likewise, Bracewell also pinpoints the contrast between the white background of some portraits and the dark sweeping Whistler-like nocturnal inky grey seascapes, grand and undoubtedly softer than the stark white backdrops.

6 The second essay is entitled "Et in suburbia Ego", which is of course an allusion to the Arcadian notion in the title of curator's earlier exhibit, "Cy Twonbly and Nicolas Poussin: Arcadian Painters", where he also intertwines works by artists belonging to different centuries. Very perceptively, as a curator well-versed in seeing paintings as soundboards of earlier influences, Cullinan puts the works of Raho in perspective within the scope of the art historical canon, highlighting affinities in approaches and style with earlier artists. Van Dyck is one of them, and similarities can be seen in the pose of his sitters and his taste for sumptuous fabrics, which were also important for Gainsborough (Cullinan calls Raho "a suburban Gainsborough" [68]).

7 Raho's flat paintings-due to compressed layers that further flatten the initial flattening photograph-conflate the British tradition of portrait painting and Pop Art (best exemplified by the portrait of Jessica with her Mickey Mouse T-shirt). Cullinan also finds that these pictures resonate with Alex Katz's and also Guy Bourdin's "glossy mannerism" and "fetishization of surface and sheen" (67).

In this game of riddles where one plays at finding echoes of former artwork haunting Raho's paintings, a few artists are perhaps overlooked. Raho's affinities with the AngloAmerican David Hockney and his subjects of modern domesticity (or of pools) are mentioned, but it seems that Edward Hopper is never cited, although Sandy Port recalls the same isolation of figures suspended in time against an architectural background, the same conjoined neatness and fuzziness, the same heightened, intimate and yet stilled, distant presence, the same white aura and quiet composure of the picture. Moreover, Raho uses the device of the double portrait split and duplicated by a mirror in Catherine, which Cullinan likens to Manet's A Bar at the Folies Bergères (1882), but the trope is used much more extensively throughout art history than what is suggested. 
For instance, Ingres used it at least thrice, in Madame Moitessier sitting (1844-56) at the National Gallery in London, La Comtesse d'Haussonville (1845) at the Frick Collection in New York, or Madame de Senonnes (1814) in Nantes. Furthermore, the underlying nineteenth-century models of the dandy and the flâneur and the sophisticated poise of society portraiture are evoked by Bracewell, especially when he talks about Catherine's portrait, but the name of Sargent is not given.

9 The conclusion is a little hasty: "Raho not only captures who we are but, more importantly, who we want to be or who we want to appear to be. In this sense, Raho is truly a painter of modern life" (73). Yet, being a painter of modern life consists not solely in capturing the narcissistic aspiration of his contemporaries.

Cullinan focuses on interpictorial references and visual quotations or influences that permeate Raho's works, but also sees in him the modernity that was detected in late nineteenth-century artists (Manet, Whistler) or mid-twentieth-century artists (Rothko). In so doing, he unwillingly but clearly classes him as outmoded or oldfashioned. Moreover, Raho's status as an artist is inferred from the way he traces his art history lineage, thereby implicitly setting his work within its scope, but he fails to characterise his figurative style in terms of what is unique, singular and new about it. True, such an approach is tempting: Raho's art, which is steeped with visual quotations, constantly seems to be looking back. But one may regret Cullinan merely connects his artwork to his predecessors', without really distilling what is specific and distinctive about it.

Cullinan does talk about the "monochrome vacuum" of the blanched background, but he could have commented on the fact that the deletion of all references estranges the characters and reduces to silence any discursive attempt to encode and label them. He could have expanded on the quality of presence and absence of these simultaneously realistic and fuzzy, precise and hazy portraits, both "existing in a concurrent reality, yet [remaining] firmly of our own world" (32) to term it as Bracewell does, and on the reasons why they are so visually arresting.

The visual neatness of quotidian presence isolated against a colourless and spare background and enhanced by a refined luminescence gives the picture a monumental abstract quality which is revelatory of "a sense of the sanctity of human life", as Bracewell puts it (20). Raho celebrates his sitters without lowly flattering them, and does not fall in the facile pitfall of derision. Their blunt and obstinate refusal of expression and smile commands the viewer's respect and implies there is more to it than meets the eye-an inner life perhaps?

13 The last essay by Catherine Wood is dense but at times written in a somewhat manneristic style which tends to dwell on her own questions on art rather than on Raho's work. She tries nonetheless to define his stance, away from both Realism or Modernism, away from our picture-saturated world, and yet steeped in it. She acknowledges Raho's bold engagement with figurative painting in an art world where mimetic verisimilitude may seem obsolete, and endeavours to analyse how his work is poised between those conflicting approaches. She adds that the initial photograph is instantaneous but the temporal element is introduced by the paintwork, thereby "[intimating] private vision" (138), and reinstating an affective bias in the pictures. 
14 Eventually, the best argument for Raho's work and evidence of his artistry is provided by the high quality reproductions of his works, successfully presented within a sleek, sober and streamlined layout, as pared-down and uncluttered as his own style. Like all new artist's monographs, such a book is not neutral in building a reputation and enhancing connoisseurs' esteem of Raho. It testifies to his achievement as a relatively young artist, especially as the authors and, significantly, the curator most of all, enshrine his work in art history.

INDEX

Keywords: figurative art, portrait, Goldsmith College

Mots-clés: art figuratif, portrait, Goldsmith College

\section{AUTHORS}

\section{MURIEL ADRIEN}

Maître de conférences

Université Toulouse 2 - Le Mirail

muriel.adrien@univ-tlse2.fr 